\title{
PENGARUH PUPUK CAIR URINE SAPI POTONG TERHADAP TINGGI TANAMAN DAN PRODUKSI TANAMAN BAYAM (Amaranthus Sp) UMUR 25 HARI
}

\author{
(Effect of Liquid Fertilizer Urine Cattle Against High Plant and Crop Production Spinach
}

(Amaranthus Sp) Age 25 Days)

\section{Supriyanto $^{1}$ dan Jamaluddin ${ }^{2}$}

email: stppsupriyanto@gmail.com

\author{
${ }^{1}$ Staf Pengajar Sekolah Tinggi Penyuluhan Pertanian Magelang \\ Jl. Magelang-Kopeng Km7 Purwosari Tegalrejo Magelang PO BOX 150 \\ ${ }^{2}$ Fungsional Penyuluh Pertanian Dinas Pertanian dan Kehutanan Kabupaten \\ Belitung \\ Jl.A.Yani No.90 Tanjung Pandan Belitung (0719) 21046
}

Diterima: 13 September 2014 Disetujui: 30 Juni 2015

\begin{abstract}
ABSTRAK
Penelitian ini dimaksudkan untuk mengetahui pengaruh penggunaan pupuk cair dari urin sapi terhadap tinggi tanaman dan hasil panen bayam (Amaranthus sp) umur 25 hari dan menentukan dosis pupuk cair dari urin sapi yang paling tepat. Permentan No.2 / Pert / HK.060 / 2/2006 pupuk organik adalah pupuk yang sebagian besar atau seluruhnya terdiri dari bahan organik yang berasal dari tumbuhan atau hewan yang telah melalui proses rekayasa, dapat berupa bahan organik padat atau cair yang digunakan mensumpai untuk memperbaiki fisik, kimia, dan tanah biologis (Suriadikarta, 2006).

Penelitian dilakukan di Laboratorium Hewan Besar STPP Magelang. Lahan yang digunakan seluas $10 \mathrm{~m} 2$ atau lebar $2 \mathrm{mx} 5 \mathrm{~m}$, dengan menggunakan urin kotoran sapi pada pertumbuhan atau produksi tinggi tanaman dan bayam. Pemupukan urin sapi potong pada bayam tanaman dilakukan pada umur 7 hari setelah tanam dengan dosis antara lain: TO (tanpa perlakuan), T1 dengan dosis $125 \mathrm{ml} / 141$ air, T2 dengan dosis $250 \mathrm{ml} / 141$ air, dan T3 menggunakan dosis $275 \mathrm{ml} / 141$ air. Variabel penelitian adalah tinggi tanaman $(\mathrm{cm})$ bayam dengan mengukur dari pangkal batang ke ujung tanaman tertinggi dan produksi tanaman bayam dihitung dengan menimbang hasil panen bayam pada umur 25 hari. Implementasi penelitian menggunakan rancangan acak lengkap (RAL) dengan empat perlakuan, yaitu: T0 sebagai kontrol yang tidak diberi urin sapi, perlakuan (T1) diberikan urin sapi yang telah difermentasi dengan dosis (125 ml / 141 air ), perlakuan (T2) diberikan pada dosis urin sapi yang difermentasi (250 ml urin / 141 air), perlakuan (T3) diberikan sepotong fermentasi urin sapi dengan dosis (375 ml urin / 141 air) dan lakukan ulangan masing-masing perlakuan 5 kali sehingga jumlah total 20 unit plot percobaan.

Tinjauan tentang pengaruh penggunaan pupuk cair dari urin sapi terhadap pertumbuhan tanaman atau bayam yang tinggi (Amaranthus sp) menunjukkan bahwa efek penggunaan pupuk cair dari urin sapi dengan dosis berbeda sangat signifikan $(\mathrm{P}<0,01)$ pada T0 $( \pm 12622 \mathrm{~cm}), \mathrm{T} 1$ $( \pm 21.144 \mathrm{~cm}), \mathrm{T} 2( \pm 20.940 \mathrm{~cm})$ dan T3 $( \pm 8.104 \mathrm{~cm})$, sedangkan bobot segar atau bayam tanaman produksi (Amaranthus sp) umur 25 hari hasil analisis statistik ANOVA menunjukkan sangat signifikan $(\mathrm{P}<0,01)$ dalam berbagai T0 $( \pm 3,86 \mathrm{~kg}), \mathrm{T} 1( \pm 14,59 \mathrm{~kg}), \mathrm{T} 2( \pm 9,79 \mathrm{~kg})$ dan
\end{abstract}


T3 $( \pm 1,85 \mathrm{~kg})$. Kesimpulan penelitian bahwa dosis pupuk cair dari urin sapi sebanyak $125 \mathrm{ml}$ / 141 air, merupakan dosis terbaik yang digunakan untuk produksi tanaman bayam 25 hari untuk menghasilkan tinggi tanaman $\pm 21,144 \mathrm{~cm}$, dan produksi berat $\pm 14,59 \mathrm{~kg} / 5 \mathrm{~m} 2$.

Kata kunci: Pupuk cair, organik, bayam

\begin{abstract}
This study is intended to determine the effect of the use of liquid manure from cattle urine on plant height and yield of amaranth (Amaranthus sp) aged 25 days and determine the dose of liquid manure from cattle urine is most appropriate. Permentan No.2/Pert/HK.060/2/2006 organic fertilizer is a fertilizer that is largely or entirely composed of organic material derived from plants or animals that have been through the process of engineering, can be solid or liquid organic material used mensumpai to improve the physical, chemical, and biological soil (Suriadikarta, 2006).

Studies carried out in the Laboratory of Large Animal STPP Magelang. Used land area of $10 \mathrm{~m} 2$ or a width of $2 \mathrm{mx} 5 \mathrm{~m}$ length, by using the urine of cattle manure on the growth or production of plant height and spinach. Beef cattle urine fertilization on plant spinach is done at the age of 7 days after planting with a dose among others: TO (without treatment), T1 with a dose of $125 \mathrm{ml} / 14$ l of water, T2 with a dose of $250 \mathrm{ml} / 14 \mathrm{l}$ of water, and T3 using doses of $275 \mathrm{ml} / 14$ l of water. Study variables were plant height $(\mathrm{cm})$ of spinach by measuring from the base of the stem to the tip of the highest plant and spinach crop production is calculated by weighing the spinach crop yields at the age of 25 days. Implementation of the study using a completely randomized design (CRD) with four treatments, ie: T0 as controls who were not given urine cattle, treatment (T1) is given urine beef that has been fermented with dose (125 $\mathrm{ml} / 14$ l of water), treatment (T2) was given at a dose of fermented cow urine ( $250 \mathrm{ml}$ urine/14 $l$ of water), treatment (T3) was given a piece of cow urine fermentation with dose $(375 \mathrm{ml}$ urine $/ 14$ l of water) and do replicates of each treatment 5 times so that the total number of 20 units experimental plots.

A review of the effect of the use of liquid manure from the urine of cattle to high plant growth or spinach (Amaranthus sp) showed that the effect of the use of liquid manure from the urine of cattle with different dose was highly significant $(P<0,01)$ at T0 $( \pm 12622 \mathrm{~cm})$, $T 1( \pm 21.144 \mathrm{~cm}), T 2( \pm 20.940 \mathrm{~cm})$ and $T 3( \pm 8.104 \mathrm{~cm})$, while the fresh weight or production plant spinach (Amaranthus sp) the age of 25 days the results of the statistical analysis ANOVA showed highly significant $(P<0,01)$ in a variety of $T 0( \pm 3.86 \mathrm{~kg}), T 1( \pm 14.59 \mathrm{~kg})$, $T 2( \pm 9.79 \mathrm{~kg})$ and $T 3( \pm 1.85 \mathrm{~kg})$. Study conclusion that a dose of liquid fertilizer from cattle urine as much as $125 \mathrm{ml} / 14$ l of water, is the best dose used for the production of spinach plants 25 days to produce $\pm 21.144 \mathrm{~cm}$ plant height, and production of weighing $\pm 14.59 \mathrm{~kg}$ $15 \mathrm{~m}^{2}$.
\end{abstract}

Keywords: Liquid fertilizers, organic, spinach

\section{PENDAHULUAN}

Permentan No.2/Pert/HK.060/2/2006 tentang pupuk organik dan pembenah tanah, dikemukakan bahwa pupuk organik adalah pupuk yang sebagian besar atau seluruhnya terdiri atas bahan organik yang berasal dari tanaman dan atau hewan yang telah melalui proses rekayasa, dapat berbentuk padat atau cair yang digunakan mensuplai bahan organik untuk memperbaiki sifat fisik, kimia, dan biologi tanah (Suriadikarta, 2006). 
Urin ternak sapi dapat dimanfaatkan sebagai pupuk organik, hal ini sesuai dengan pendapat (Susanto 2004) bahwa, pupuk cair urin ternak sapi adalah baik sebagai sumber hara tanaman, bahan ini merupakan sumber pupuk yang dapat dimanfaatkan dengan murah. Menurut hasil penelitian bahwa satu ekor ternak sapi memproduksi rata-rata 5 liter urin setiap hari (Ramadan, 2008), sampai saat ini urin belum banyak dimanfaatkan sebagai pupuk tanaman secara terpisah dari feses, hal ini disebabkan karena belum adanya informasi mengenai aplikasi yang tepat dalam pemupukan. Pemanfaatan urin sapi potong sebagai pupuk organik cair salah satunya untuk pupuk tanaman sayuran khususnya tanaman bayam, urine mengandung mikrobia dalam jumlah cukup guna berperanan dalam proses dekomposisi bahan organik (Suriadikarta, 2006). Tujuan dari penelitian ini adalah ingin mengetahui pengaruh penggunaan pupuk cair dari urin sapi potong terhadap tinggi tanaman dan produksi tanaman bayam (Amaranthus sp) umur 25 hari dan mengetahui dosis pupuk cair dari urine sapi potong yang paling tepat.

\section{Landasan Teori}

Limbah ternak sapi adalah sisa buangan dari suatu kegiatan usaha peternakan seperti usaha pemeliharaan ternak, rumah potong hewan, pengolahan produk ternak, dan sebagainya. Limbah tersebut meliputi limbah padat dan limbah cair seperti feses, urin, sisa makanan, embrio, kulit telur, lemak, darah, bulu, kuku, tulang, tanduk, isi rumen, dan lainlain (Sihombing, 2000).

Urine adalah zat-zat yang diskresikan melalui ginjal, zat-zat yang didapatkan didalamnya adalah zat makanan yang sudah dicerna, diserap dan bahkan sudah dimetabolisme dalam sel-sel tubuh, kemudian oleh satu dan lain hal dikeluarkan melalui ginjal dalam saluran urine. Sifat fisik dan kimianya dipengaruhi oleh banyak faktor (Parakasih, 2000).

Manfaat pupuk organik adalah menambah zat atau unsur hara dalam tanah yang miskin atau pun kurang subur, memiliki kandungan unsur hara yang kurang mencukupi bagi pertumbuhan tanaman, sehingga pemberian pupuk yang bersifat organik secara langsung akan mampu menambah unsur hara yang kurang memadai tersebut serta memberikan tambahan unsur hara baru yang belum ada (Agung, 2008).

Manfaat urin ternak sapi digunakan dalam pembuatan pupuk organik cair dari urine ternak sapi potong karna didalam

limbah ternak masih mengandung zat mikro organisme yang potensial untuk dimanfaatkan. Limbah ternak kaya akan nutrient (zat makanan) seperti protein, lemak, bahan ekstrak tanpa nitrogen (BETN), vitamin, mineral, mikroba atau biota, dan zat-zat yang lain (unidentified subtances). Limbah ternak dapat dimanfaatkan untuk bahan makanan ternak, pupuk organik (Nurtjahya dkk., 2006).

Fermentasi urin adalah proses produksi energi dalam sel dalam keadaan anaerobik (tanpa oksigen). Secara umum, fermentasi adalah salah satu bentuk respirasi aerobik, akan tetapi terdapat definisi yang lebih jelas yang mendefinisikan fermentasi sebagai respirasi dalam lingkungan anaerobik dengan tanpa akseptor elektron eksternal (Wikipedia, 2013).

Pikiran Rakyat (2006), fermentasi berasal dari bahasa latin ferfere yang artinya mendidihkan, yaitu berdasarkan ilmu kimia terbentuknya gas-gas dari suatu cairan kimia yang pengertiannya berbeda dengan air mendidih. Gas yang terbentuk tersebut di 
antaranya karbondioksida $\left(\mathrm{CO}_{2}\right)$. Fermentasi terbagi dua tipe berdasarkan tipe kebutuhan akan oksigen yaitu tipe aerobik dan anaerobik yaitu: 1.Tipe aerobik adalah fermentasi yang pada prosesnya memerlukan oksigen. Semua organisme untuk hidupnya memerlukan sumber energi yang diperoleh dari hasil metabolisme bahan pangan di mana organisme itu berada. Mikroorganisme adalah organisme yang memerlukan energi tersebut. Bahan energi yang paling banyak digunakan mikroorganisme untuk tumbuh adalah glukosa, dengan adanya oksigen maka mikroorganisme dapat mencerna glukosa menghasilkan air, karbondioksida dan sejumlah besar energi. 2.Tipe anaerobik adalah fermentasi yang prosesnya tidak memerlukan oksigen. Beberapa mikroorganisme dapat mencerna bahan energinya tanpa oksigen, jadi hanya sebagian bahan energi itu dipecah yang dihasilkan adalah sebagian dari energi, karbondioksida dan air, termasuk sejumlah asam laktat, asetat, etanol, asam volatile, alkohol, dan ester.

Menurut Pramonosidi (2007) dalam fermentasi urine sapi untuk dijadikan pupuk cair, bahan-bahan yang diperlukan adalah: urin sapi 100 liter, tepung lengkuas $1 \mathrm{~kg}$, tepung temu ireng $1 \mathrm{~kg}$, tepung jahe $1 \mathrm{~kg}$, tepung kencur $1 \mathrm{~kg}$, tepung kunyit $1 \quad \mathrm{~kg}$, tepung sambiloto/wimbo $1 \mathrm{~kg}$, bawang putih 0,5 $\mathrm{kg}$, jeringau $0,1 \mathrm{~kg}$, bangle $0,1 \mathrm{~kg}$, tetes 2 liter dan $\mathrm{EM}_{4}$ pertanian $50 \mathrm{ml}$.

Hasil analisa laboratorium terhadap sifat urine sapi sebelum dan sesudah difermentasi dapat dijelaskan dari hasil penelitian Naswir (2003), yang dapat dilihat pada Tabel 1.

Tabel 1. Beberapa Sifat Urin Ternak Sapi Sebelum dan Sesudah Difermentasi

\begin{tabular}{ccccccccc}
\hline Perlakuan & $\mathrm{N}$ & $\mathrm{P}$ & $\mathrm{K}$ & $\mathrm{Ca}$ & $\mathrm{Mg}$ & $\mathrm{Fe}$ & $\mathrm{Zn}$ & Warna \\
\hline Sebelum Fermentasi & 1,1 & 0,5 & 0,9 & 1,1 & 0,2 & 3726 & 101 & Kuning \\
Sesudah Fermentasi & 2,7 & 1,5 & 1,3 & 5,8 & 4,2 & 7692 & 624 & Hitam
\end{tabular}

Sumber: Naswir (2003)

Menurut Susanto (2004) pupuk cair sumber unsur hara tanaman. Melalui urine adalah pupuk yang baik sebagai pengumpulan pupuk cair yang baik, maka bahan ini merupakan sumber pupuk yang Jenis dan kandungan unsur hara yang dapat dimanfaatkan dengan harga murah. terdapat pada urine cair ternak dapat dilihat pada Tabel 2.

\begin{tabular}{ccccc}
\hline \hline \multirow{2}{*}{ Nama Ternak } & \multicolumn{3}{c}{ Kandungan hara (\%) } & \multirow{2}{*}{$\begin{array}{c}\text { Kadar air } \\
(\%)\end{array}$} \\
\cline { 2 - 4 } & $\mathrm{N}$ & $\mathrm{P}$ & $\mathrm{K}$ & \\
\hline
\end{tabular}

Tabel 2. Kandungan Hara Kotoran Ternak Cair

$\begin{array}{lllll}\text { Sapi } 1.00 & 0,50 & 0,50 & 92 & \\ \text { Kambing } & 1.50 & 0,13 & 1,80 & 85 \\ \text { Domba } 1,35 & 0,05 & 2,10 & 85 & \\ \text { Ayam } & 1,00 & 0,80 & 0,40 & 55\end{array}$

Kerbau $1,00 \quad 0,15 \quad 1,50 \quad 92$

Sumber: Marsono dan Sigit (2002) 
Pemanfaatan suatu limbah usaha peternakan terutama ternak sapi potong, limbah ternak seperti, urin dapat dimanfaatan sebagai pupuk organik cair, perlu adanya perlakuan atau proses fermentasi, sehingga dapat di aplikasi pada tanaman bayam. Pemanfaatan tersebut juga menghasilkan nilai tambah yang bernilai ekonomis, serta pemanfaatan lain adalah penggunaan urine dari ternak untuk campuran dalam pembuatan pupuk cair maupun penggunaan lainnya. Bertolak dari kegunaan dan prinsip ekologi dari penggunaan pupuk cair dari urine ternak sapi tersebut, serta dapat menekan aktivitas hama dan penyakit, pertumbuhan dan produksi tanaman bayam dapat meningkat baik kualitas maupun kuantitasnya, selain itu penggunaan pupuk cair dari urin ini juga ramah lingkungan (Anomin, 2012).

Peranan utama kandungan nitrogen bagi tanaman bayam adalah untuk merangsang pertumbuhan secara keseluruhan, khususnya batang, cabang, dan daun. Selain itu, nitrogen pun berperan penting dalam pembentukan hijau daun atau krolofil yang sangat berguna dalam proses fotosintesis. Fungsi lainnya ialah membentuk protein, lemak, dan berbagai persenyawaan organik lainnya (Detik Forum, 2008). Selanjutnya Wibowo (2008) menyatakan bahwa, khusus limbah ternak cair berupa urin sapi juga dapat dimanfaatkan sebagai perangsang perkembangan tanaman karena mengandung hormon. Limbah ini sebaiknya diberikan menjelang atau sebelum waktu tanam dengan mengencerkannya terlebih dahulu.

\section{MATERI DAN METODE}

\section{A. Lokasi dan Waktu Pengkajian}

Pengkajian dilaksanakan di STPP Magelang di Laboratorium Ternak Besar pada tanggal Maret sampai dengan 20 Juli 2012.

\section{B. Materi Kajian}

Materi kajian adalah pengaruh pupuk cair urine sapi yang terdiri dari (urin sapi 10 liter, lengkuas 2 ons, kunyit 2 ons, temu ireng 2 ons, jahe 2 ons, kencur 2 ons, sambiloto 2 ons, dan EM-4 $50 \mathrm{ml}$ ) terhadap tinggi tanaman dan produksi tanaman bayam (amaranthus $s p$ ) umur 25 hari. Sedangkan alat yang digunakan: ember 1 buah, pengaduk 1 buah, saringan 1 buah, botol bekas 5 buah, drum plastik 2 buah, timbangan 1 buah, dan blender 1 buah.

\section{Metode}

\section{Metode Pelaksanaan Kajian}

Kajian dilaksanakan di Laboratorium Ternak Besar STPP Magelang. Lahan digunakan seluas $10 \mathrm{~m}^{2}$ atau lebar $2 \mathrm{~m} \mathrm{x}$ panjang $5 \mathrm{~m}$, dengan menggunakan pupuk urin dari sapi potong terhadap pertumbuhan atau tinggi dan produksi tanaman bayam. Adapun kegiatan yang dilakukan meliputi:

a. Pengolahan lahan dibuat bedengan/petak dengan lebar $1 \mathrm{~m}$ dan panjang $1 \mathrm{~m}$ (luas tiap bedengan $1 \mathrm{~m}^{2}$ ) sebanyak 20 bedengan atau petak pembuatan saluran drainase $30 \mathrm{~cm}$ di antara bedengan petak.

b. Proses fermentasi pupuk cair, urin sapi potong murni yang sudah disaring masuk dalam drum kemudian ditambah dengan lengkuas, kunyit, temu ireng, jahe, kencur, sambiloto yang telah di blender, kemudian dicampurkan dengan EM4 dan dilakukan pengadukan pagi dan sore. Drum ditutup rapat dan proses fermentasi membutuhkan waktu selama 14 hari

(Pramonosidi, 2007). 
c. Perlakuan benih bayam dengan dicampur dengan abu. Benih bayam yang digunakan dalam kajian adalah sebanyak 20 gr dicampur dengan abu dapur 2000 gr serta diaduk secara merata dan kemudian benih siap untuk ditanam/taburkan pada petak bedengan yang telah tersedia.

d. Penanaman langsung pada bedengan atau petak tanpa adanya perlakuan penyemaian benih, biji bayam sudah dicampur abu disebarkan langsung di atas bedengan atau petak dengan jarak antara barisan $20 \mathrm{~cm}$ dan arahnya membujur dari barat ke timur. Setelah disebarkan, benih segera ditutup dengan tanah halus dan disiram hingga cukup basah, penanaman dilakukan pada pagi hari.

e. Pemeliharaan tanaman bayam adalah pada fase awal pertumbuhan, dilakukan penyiraman rutin dan intensif 1-2 kali sehari apabila tidak ada hujan. Waktu yang paling baik untuk penyiraman tanaman bayam adalah pagi atau sore hari.

Penyiraman dengan menggunakan gembor yang disiramkan secara merata pada tanaman. Penggemburan tanah di sekitar tanaman sambil membuang gulma dan membunuh hama disekitar tanaman bayam.

f. Pemupukan urin sapi potong pada tanaman bayam dilakukan pada umur 7 hari setelah tanam dengan dosis antara lain: TO (Tanpa perlakuan), T1 dengan dosis 125 $\mathrm{ml} / 141$ air, T2 dengan dosis 250 $\mathrm{ml} / 141$ air, dan T3 menggunakan dosis $275 \mathrm{ml} / 141$ air. Penyemprotan dengan menggunakan hand sprayer dengan cara disemprot merata pada tanaman.

g. Pasca panen pada saat tanaman bayam berumur 25 hari setelah tanam.

\section{Variabel Kajian}

Variabel yang diamati dalam kajian ini adalah: a. Tinggi tanaman $(\mathrm{cm})$ bayam dengan cara mengukur dari pangkal batang sampai ujung tanaman tertinggi. b. Produksi tanaman bayam di hitung dengan cara menimbang hasil panen tanaman bayam pada umur 25 hari.

\section{Pelaksanaan Kajian}

Pelaksanaan kajian menggunakan Rancangan Acak Lengkap (RAL) dengan 4 perlakuan yaitu: T0 sebagai kontrol yang tidak diberi urin sapi potong, perlakuan (T1) diberikan urine sapi potong yang sudah difermentasi dengan dosis $(125 \mathrm{ml}$ /14 1 air), perlakuan (T2) diberi urin sapi fermentasi dengan dosis (250 $\mathrm{ml}$ urin /14 1

Tabel 3. Rancangan Perlakuan dan Ulangan air), perlakuan (T3) diberi urin sapi potong fermentasi dengan dosis (375 $\mathrm{ml}$ urin/14 1 air) dan dilakukan ulangan masing-masing 5 kali perlakuan sehingga jumlah keseluruhan 20 satuan petak percobaan.

\section{Rancangan Penelitian}

Pengaruh penggunaan dosis pupuk cair dari urin sapi potong terhadap tinggi dan produksi tanaman bayam diaplikasikan menggunakan sistem Rancangan Acak Lengkap (RAL) searah dengan 4 perlakuan (treatmen) masing-masing perlakuan antara lain: (T0, T1, T2, T3), menggunakan media bedengan atau petak sebanyak 20 unit, 
masing-masing $1 \mathrm{~m}^{2}$ dengan ukuran $100 \times 100$

$\mathrm{cm}^{2}$. Pelaksanaan perlakuan (treatmen) dan

ulangan dapat dilihat pada Tabel 3.

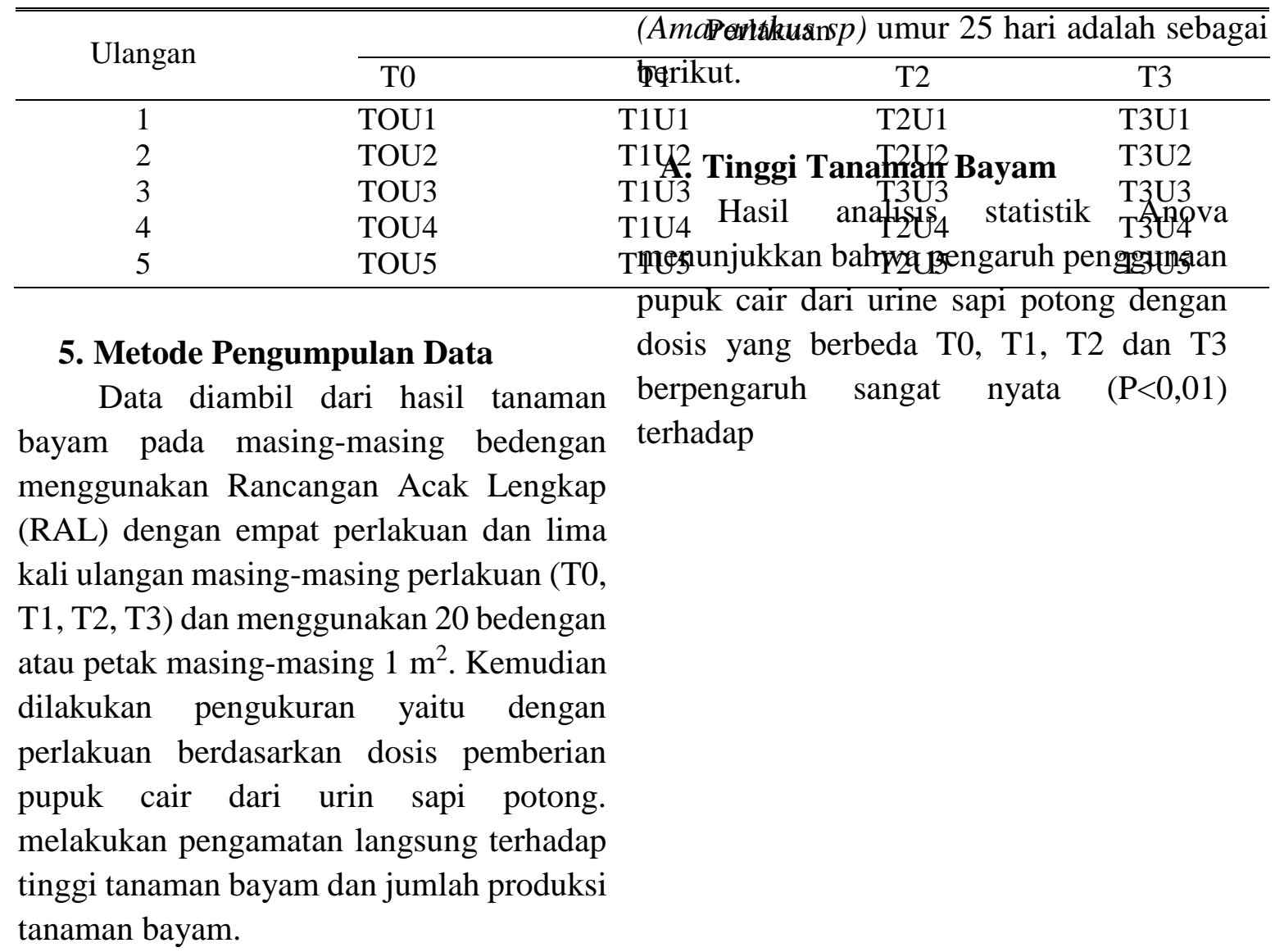

\section{Metode Analisis Data}

Metode analisis data yang digunakan adalah analisis of variance (Anova), dan jika terjadi perbedaan antar percobaan, maka untuk mengetahui percobaan yang menunjukkan perbedaan maka digunakan metode Dunnet't, dengan taraf signifikansi 0,5\%. Untuk pelaksanaan analisis menggunakan bantuan program Statistical Product and Service Solutions (SPSS) 15.

\section{HASIL DAN PEMBAHASAN}

Hasil kajian pengaruh penggunaan pupuk cair dari urin sapi potong terhadap pertumbuhan atau tinggi tanaman bayam dan berat segar atau produksi tanaman bayam 
Pertumbuhan tingggi tanaman bayam T0 sebagai kontrol dari $\mathrm{T}_{1}, \mathrm{~T}_{2}$ dan $\mathrm{T}_{3}$ hal ini menunjukan bahwa adanya perbedaan tinggi $(\mathrm{cm})$ tanaman bayam, Peningkatan pertumbuhan tinggi tanaman bayam pada
1. Pemberian dosis pupuk sesuai dengan anjuran diperlukan bagi tanaman bayam, hal ini sesuai dengan pendapat Pramonosidi (2007) menyatakan bahwa, cara penggunaan tinggi tanaman bayam (Amaranthus sp.

Tabel 4. Rata-rata Tinggi Tanaman (cm)

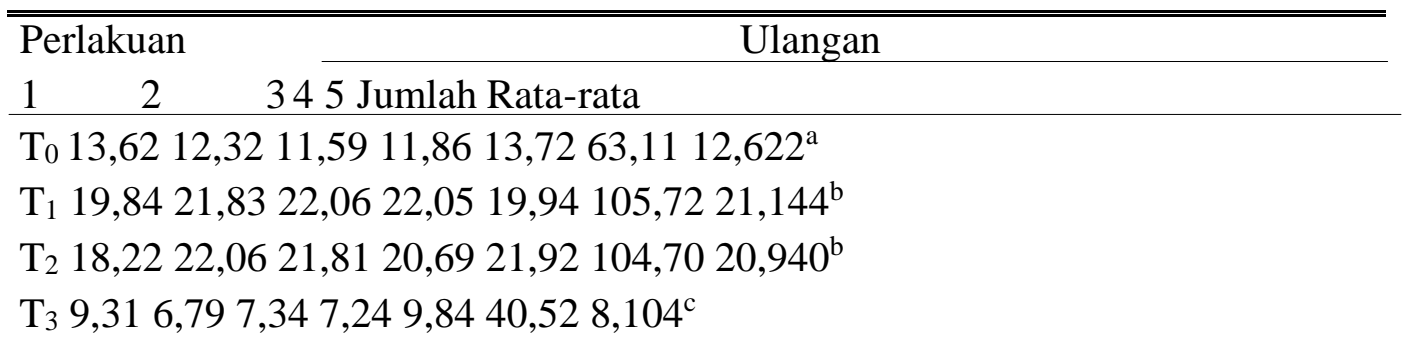

Keterangan: (a b dan c ) Superskrip yang berbeda pada kolom yang sama menunjukkan perbedaan yang nyata $(\mathrm{P}<0,05)$

Berdasarkan analisis statistik anjuran dosis yang berbeda (T0), (T1), (T2), menunjukkan bahwa: a. T0 berbeda nyata dan (T3), ada perbedaan nyata $(\mathrm{P}<0,05)$ terhadap T1, T2, dan $\mathrm{T} 3(\mathrm{P}<0,05)$, b. T1 terhadap tinggi tanaman bayam.

berbeda nyata terhadap $\mathrm{T} 0$ dan $\mathrm{T} 3$

$(\mathrm{P}<0,05)$, dan tidak berbeda nyata terhadap $\mathrm{T} 2$, c. T2 berbeda nyata terhadap T0 dan T3 $(\mathrm{P}<0,05)$, sedangkan terhadap $\mathrm{T} 1$ tidak berbeda nyata $(\mathrm{P}>0,05)$. T3 berbeda nyata terhadap T0, T1 dan T2 $(\mathrm{P}<0,05)$.

Hasil tersebut menunjukkan pemberian

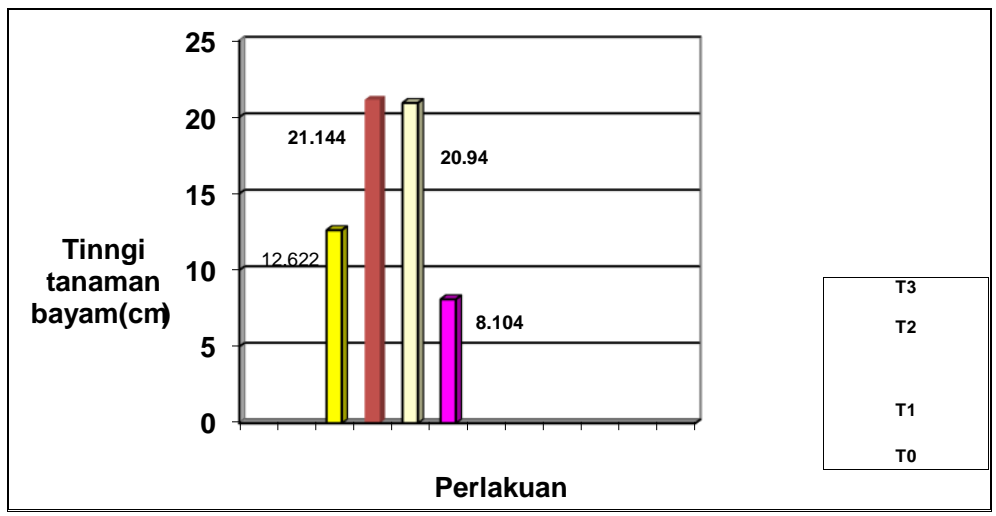

Gambar 1. Grafik tinggi tanaman bayam umur 25 hari

$\mathrm{T}_{1}$ dan $\mathrm{T}_{2}$ hal ini kemungkinan disebabkan karena:

\section{pupuk urin sapi potong dengan}

Pada perlakuan T0 tinggi tanaman bayam \pm $12,620 \mathrm{~cm}$, T1 tinggi tanaman bayam \pm $21,144 \mathrm{~cm}, \mathrm{~T} 2$ tingggi tanaman bayam \pm 20,940 cm, sedangkan T3 tinggi tanaman bayam $\pm 8,104 \mathrm{~cm}$ dapat dilihat pada Gambar 1 dibawah ini. 
adalah dosis pupuk cair urin sapi potong yang digunakan $250 \mathrm{ml}$ dicampur dengan 14 liter air disemprotkan secara merata pada bagian tanaman.

2. Kandungan pupuk yang digunakan pada dosis diatas (perlakuan T1 dan T3) mempunyai kandungan N.P.K yang sesuai dengan kebutuhan tanaman, hal ini sesuai dengan pendapat Annas (2007) menyatakan bahwa, urine ternak sapi yang diolah menjadi pupuk cair kaya akan unsur $\mathrm{N}, \mathrm{P}, \mathrm{K}$ yang dibutuhkan tanaman dalam pembentukan batang, daun untuk tumbuh dan makin hijau serta menghindari serangan hama daun, karena banyak kandungan unsur hara makro pada kotoran atau limbah ternak berbentuk padat dan cair.

3. Pupuk yang digunakan merupakan pupuk organik karena hasil campuran dari: a. Urin sapi potong (10 ltr) mengadung unsur nitrogen $(\mathrm{N})$ pospor (P) dan kalium (K), b. Lengkuas (2 ons) mempunyai kandungan minyak atsiri dan xantorizal bermanfaat sebagai pemacu pertumbuhan dan produksi tanaman, c. Kencur (2 ons) mempunyai kandungan berupa minyak atsiri, turmeron, zink beren, kencur juga bermanfaat sebagai daya tahan tubuh, memacu pertumbuhan tanaman, d. Temu ireng (2 ons) mempunyai kandungan minyak atsiri dan xantorizal, e. Jahe (2 ons) mempunyai kandungan zink beren, Turmeron, curcumin, bermanfaat sebagai daya tahan tubuh serta anti bakteri, f. Kunyit (2 ons) bermanfaat sebagai anti bakteri, pemacu pertumbuhan, g. Samiloto
(Andrographis paniculata) (2 ons) mempunyai kandungan fagositosis leukosit, jenis senyawa lakton utama, yaitu deoksiandrografolida, neoandrografolida dan didehidroandrografolida bermanfaat sebagai antiseptik. Menurut Muhlisin (1999) mengatakan bahwa, komoditas temu-temuan dan empon-empon, sudah dikenal oleh masyarakat masing-masing komoditas, budidaya, manfaat, dan beberapa khasiatnya dapat mendatangkan pendapatan tambahan bagi petani dan keluarga serta devisa bagi negara.

Sutanto (2006) menyatakan bahwa, gambaran umum pupuk organik merupakan: a. Sumber makanan bagi tanaman dan tanah, b. Selain Nitrogen, Pospor dan Kalium (NPK) pupuk organik juga mengandung unsur hara yang lain, c. Memperbaiki stuktur atau tekstur tanah, d. Pertumbuhan tanaman memperoleh perlindungan dari pestisida alami.

Selanjutnya Setjamidjaja dan Wirasmoko (2000), nitrogen berperan dalam merangsang pertumbuhan vegetatif sehingga tanaman tumbuh tinggi, sedangkan Morgan (1999) dan Aprianto (2008) dalam Agromedia

(2007) menyatakan bahwa, nitrogen merupakan unsur penting dalam

pertumbuhan dan membudidayakan tanaman dapat mengalami pertumbuhan cepat apabila kebutuhan hara tanaman tersebut tersedia dalam jumlah yang cukup. Raihan dan Nurtirtayani (2001) mengatakan bahwa, kandungan nitrogen total tanah mengalami peningkatan dengan pemberian pupuk organik. Pori tanah yang lebih besar akan meningkatkan perkembangan akar, dan kemampuan akar menyerap air dan unsur hara pada akhirnya mempengaruhi pertumbuhan serta hasil produksi tanaman.

4. Kandungan $\mathrm{EM}_{4}$ dalam pupuk membantu mempercepat proses pembuatan pupuk 
dan meningkatkan kualitasnya, selain itu $\mathrm{EM}_{4}$ juga dapat bermanfaat memperbaiki struktur dan tekstur tanah menjadi lebih baik, serta menyuplai unsur hara yang dibutuhkan tanaman dengan demikian, penggunaan $\mathrm{EM}_{4}$ akan membuat tanaman lebih subur, sehat dan relatif tahan terhadap serangan hama dan penyakit.

Menurut Indriani dan Hety (2007) menyatakan bahwa, manfaat $\mathrm{EM}_{4}$ bagi tanaman dan tanah antara lain: a.

Memperbaiki sifat fisik, kimia, dan biologi tanah, b. Menyediakan unsur hara yang dibutuhkan tanaman, c. Menyehatkan tanaman, meningkatkan produksi tanaman, dan menjaga kestabilan produksi, $d$. Meningkatkan kualitas bahan organik sebagai pupuk.

Pada perlakuan T3, pertumbuhan tanaman bayam sangat kerdil atau pendek $( \pm 8,1 \mathrm{~cm})$ dibandingkan dengan $\mathrm{T} 0( \pm 12,52$ $\mathrm{cm}$ ), hal ini disebabkan kemungkinan pemberian dosis pupuk urine lebih banyak atau tidak sesuai dengan anjuran lebih besar dari $250 \mathrm{ml} / 14$ ltr air, kemungkinan kandungan nitrogen terlalu tinggi.

Peranan utama nitrogen bagi tanaman adalah untuk merangsang pertumbuhan secara keseluruhan, khususnya batang, cabang dan daun. Tanaman kekurangan unsur nitrogen maka gejala yang timbul adalah daun pucat kekuning-kuningan, nitrogen penting untuk membangun material tanaman, merangsang tumbuhnya vegetatif yang cepat sehingga tanaman tumbuh tinggi dan memiliki warna hijau sehat. Nitrogen adalah pembentuk utama protein yang menyusun protoplasma dari satu tanaman dan bahan yang membentuk tubuh tanaman, khususnya batang dan daun tanaman. Akibat dari kekurangan unsur pospor (P) pada tanaman adalah perkembangan akar menjadi terhambat dan batang menjadi kurus (Detik Forum, 2008).

Pemupuk organik adalah ketersediaan pupuk yang mempunyai kandungan nitrogen $(\mathrm{N})$ adalah merupakan unsur hara utama bagi pertumbuhan tanaman, apabila kekurangan unsur nitrogen menyebabkan terhambatnya pertumbuhan vegetatif pada tanaman, hal ini sesuai dengan pendapat Pratikno (2001) menyatakan bahwa, pemupukan organik adalah ketersedian pupuk mempunyai kandungan unsur nitrogen yang banyak digunakan pada tanaman sayuran-sayuran.

\section{B. Produksi Tanaman Bayam}

Hasil analisis statistik anova dan berbagai perlakuan T0 (kontrol), T1, T2 dan T3 menunjukkan bahwa, pengaruh penggunaan pupuk cair dari urin sapi potong terhadap produksi tanaman berpengaruh sangat nyata $(\mathrm{P}<0,01)$ terhadap produksi berat segar tanaman bayam umur 25 hari.

Pada perlakuan T1, produksi tanaman bayam $\left( \pm 14,59 \mathrm{~kg} / 5 \mathrm{~m}^{2}\right)$ dan $\mathrm{T} 2$ produksi tanaman bayam $\left( \pm 9,79 \mathrm{~kg} / 5 \quad \mathrm{~m}^{2}\right)$, menunjukkan adanya peningkatan produksi tanaman dibandingkan dengan T0 (kontrol), sedangkan pada T3 produksi tanaman bayam $\left( \pm 1,85 \quad \mathrm{~kg} / 5 \quad \mathrm{~m}^{2}\right)$, menunjukkan penurunan produksi tanaman bayam dibandingkan dengan T0 (kontrol). Peningkatan produksi tanaman bayam pada umur 25 hari pada perlukan T1 dan T2 kemungkinan disebabkan pupuk yang digunakan termasuk pupuk organik yang banyak mengadung unsur hara $(\mathrm{N}, \mathrm{P}, \mathrm{K})$, hal ini sesuai dengan pendapat Murbandono (2006), tujuan pemupukan adalah untuk menambah hara tanaman agar dapat diserap oleh tanaman sehingga menghasilkan pertumbuhan dan produksi yang tinggi, karena tercukupinya kandungan 
Tabel 5. Rata-rata Produksi Tanaman Bayam $(\mathrm{kg})$

\begin{tabular}{|c|c|c|c|c|c|c|c|c|c|}
\hline \multirow{2}{*}{ Perlakuan } & \multicolumn{7}{|c|}{ Ulangan } & \multirow{2}{*}{ Jumlah } & \multirow{2}{*}{ Rata-rata } \\
\hline & 1 & 2 & & 3 & 4 & 5 & & & \\
\hline & $\mathrm{T} 0$ & 3,44 & 6,01 & 3,01 & 2,46 & 4,38 & 82,24 & $3,86^{\mathrm{a}}$ & \\
\hline & $\mathrm{T} 1$ & 14,03 & 13,07 & 16,62 & 12,91 & 16,36 & 72,99 & $14,59^{\mathrm{b}}$ & \\
\hline & $\mathrm{T} 2$ & 7,92 & 8,14 & 9,29 & 10,07 & 13,53 & 48,95 & $9,79^{c}$ & \\
\hline & $\mathrm{T} 3$ & 2,6 & 1,43 & 2,4 & 1,32 & 1,52 & 9,27 & $1,85^{\mathrm{a}}$ & \\
\hline
\end{tabular}

Keterangan: (a b dan c) Superskrip yang berbeda pada kolom yang sama menunjukkan perbedaan yang nyata $(\mathrm{P}<0,05)$.

Berdasarkan analisis statistik Hasil tersebut menunjukkan pemberian menunjukkan bahwa: 1 . T0 berbeda nyata pupuk urine sapi potong dengan dosis yang terhadap T1 dan T2 $(\mathrm{P}<0,05)$, sedangkan berbeda (T1), (T2), dan (T3), ada perbedaan dengan T3 tidak berbeda nyata $(\mathrm{P}>0,05), 2$. nyata $(\mathrm{P}<0,05)$ terhadap produksi tanaman T1 berbeda nyata terhadap T0, T2 dan T3 bayam umur 25 hari. Untuk lebih jelasnya, $(\mathrm{P}<0,05), 3$. T2 berbeda nyata terhadap T0, grafik rata-rata produksi tersebut dapat T1 dan T3, $(\mathrm{P}<0,05), 4$. T3 berbeda nyata dilihat pada sajian Gambar 2 berikut: terhadap T1 dan T2 $(\mathrm{P}<0,05)$, sedangkan dengan T0 tidak berbeda nyata $(\mathrm{P}>0,05)$

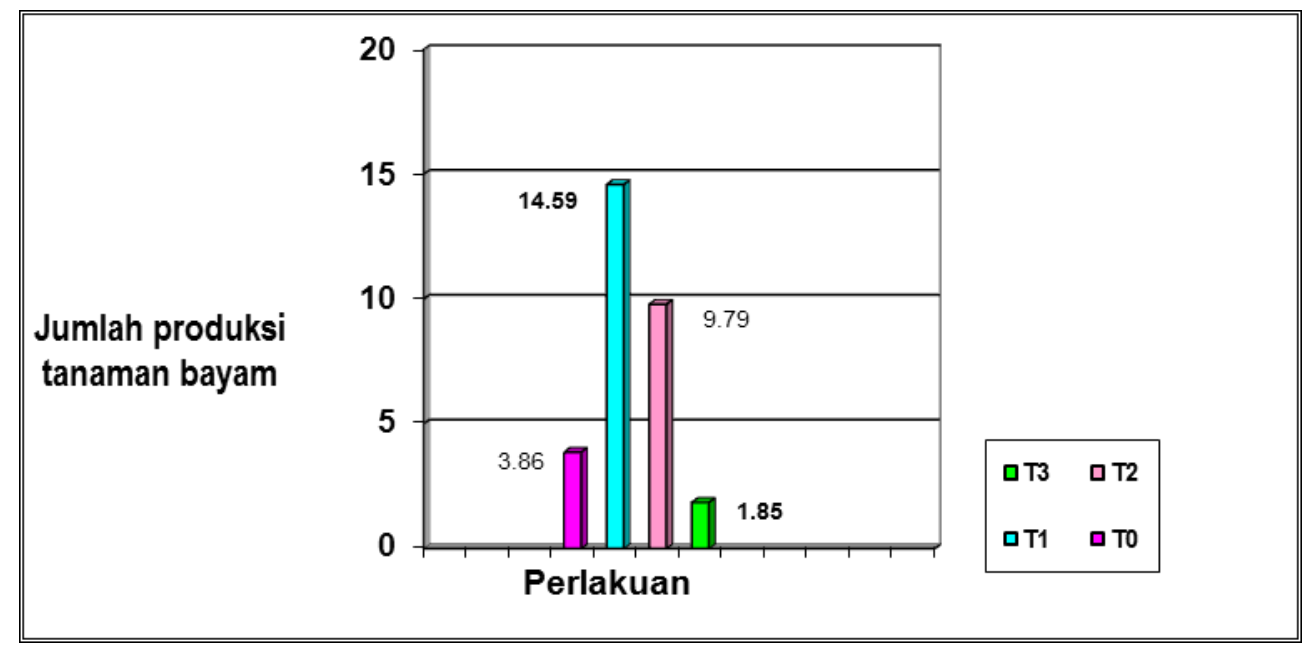

Gambar 2. Nilai rata-rata produksi tanaman bayam umur 25 hari

unsurunsur nitrogen, pospor dan kalium

(NPK) yang terdapat dalam pupuk cair dari urin sapi potong.

Makin banyak pupuk organik yang diberikan, maka kondisi tanah akan makin baik diantaranya struktur, fisik, kimiawi dan biologis tanah dengan demikian penyerapan hara oleh perlakuan tanaman makin intensif, jika kosentrasi hara dalam tanaman sangat tercukupi, maka laju pertumbuhan dan produksi meningkat sehingga tanaman menjadi subur

(Agromedia, 2007).
Peningkatan produksi tanaman bayam segar setiap perlakuan diduga akibat dosis pumupukan yang berbeda-beda, dimana dari tiap perlakuan mempunyai kandungan unsur nitrogen, fosfor, dan kalium yang berbedabeda. Akan tetapi dapat kita lihat disini bahwa pupuk cair urin sapi potong memang sangat dibutuhkan oleh tanaman bayam untuk dapat membantu proses pertumbuhan yang optimal dan produksi yang tinggi, sesuai dengan pendapat Syarif dan Sumoprastowo (1982) bahwa, tujuan pemupukan adalah untuk menambah hara tanaman agar dapat diserap oleh tanaman sehingga menghasilkan 
pertumbuhan atau tinggi tanaman dan produksi tanaman tinggi atau meningkat.

Pupuk organik yang digunakan sesuia dengan dosis yang dianjurkan, hal ini sesuai dengan pendapat Pramonosidi (2007) menyatakan bahwa, cara penggunaan pupuk organik cair dan aplikasi untuk tanaman, dosis yang dianjurkan adalah dosis pupuk yang digunakan $250 \mathrm{ml}$ dicampur dengan 14 liter air disemprotkan secara merata pada bagian tanaman.

Simamora dan Saludik (2006) menyatakan bahwa, pemakaian pupuk sangat dianjurkan karena dapat memperbaiki produktifitas tanah, baik secara fisik, kimia, maupun biologi tanah.

Secara fisik pupuk cair dari urine sapi potong bisa menggemburkan tanah, memperbaiki aerase dan drainase dan meningkatkan pengikatan antar partikel dan kapasitas mengikat air.

Perlakuan T3 produksi tanaman bayam $\left( \pm 1,85 \mathrm{~kg} / 5 \mathrm{~m}^{2}\right)$ adanya penurunan hasil sangat jauh berbeda bila dibadingkan dengan perlakuan T0 (kontrol), hal ini disebabkan kerena pemberian dosis lebih banyak (375 ml/14 ltr air) atau tidak sesuia dengan dosis anjuran, kemungkinan kandungan nitrogen terlalu tinggi.

Hasil penelitian Raihan dan Nurtirtayani (2001) menyatakan bahwa, kandungan Nitrogen total tanah mengalami peningkatan dengan pemberian pupuk organik. Pori tanah yang lebih besar akan meningkatkan perkembangan akar, dan kemampuan akar menyerap air dan unsur hara yang pada akhirnya dapat mempengaruhi pertumbuhan serta hasil produksi tanaman.

Peranan utama nitrogen bagi tanaman adalah untuk merangsang pertumbuhan secara keseluruhan, khususnya batang, cabang dan daun. Tanaman yang kekurangan unsur nitrogen $(\mathrm{N})$ maka gejala yang timbul adalah daun pucat kekuningkuningan, nitrogen penting untuk membangun material tanaman, merangsang tumbuhnya vegetatif yang cepat sehingga tanaman tumbuh tinggi dan memiliki warna hijau sehat. Nitrogen adalah pembentuk utama protein yang menyusun protoplasma dari satu tanaman dan bahan yang membentuk tubuh tanaman, khususnya batang dan daun tanaman. Akibat dari kekurangan unsur pospor $(\mathrm{P})$ pada tanaman adalah perkembangan akar menjadi terhambat dan batang menjadi kurus (Detik Forum, 2008).

\section{KESIMPULAN DAN SARAN}

\section{Kesimpulan}

Hasil kajian penelitian pada pelaksanaan STPP untuk mengetahui pengaruh penggunaan pupuk cair dari urin sapi potong terhadap produksi tanaman bayam (Amaranthus sp) umur 25 hari dapat disimpulkan bahwa dosis pupuk cair dari urine sapi potong sebanyak $125 \mathrm{ml} / 14 \mathrm{l}$ air, merupakan dosis terbaik yang digunakan untuk produksi tanaman bayam 25 hari dengan menghasilkan tinggi tanaman ratarata $\pm 21,14 \mathrm{~cm}$, dan produksi sebanyak rata-rata $\pm 14,59 \mathrm{~kg} / 5 \mathrm{~m}^{2}$.

\section{Saran}

Paket teknologi tersebut dapat digunakan sebagai materi penyuluhan pada kelompok tani yang membutuhkan.

\section{DAFTAR PUSTAKA}

Agromedia. 2007. Petunjuk Pemupukan. Jakarta: Agromedia Pustaka. 
Agung, S. 2008. Pengertian Pupuk

Organik Cair Mikroorganisme.

http://www.

insidewinme.pembuatan-

pupukurine-cair-sebagai.html.

Diakses pada 25 Januari 2012.

Annas. 2007. Pembuatan Pupuk Urine Sapi sebagai Pupuk Daun.

http://matoa.org/tata-

carapembuatan-kompos-cair/.

Diakses pada 20 Januari 2012.

Anomin. 2012. Pemanfaatan Limbah Peternakan pada Tanaman

Sayuuran.

(http://dinsembawang.wetpaint.co

$\mathrm{m} /$ page/Pestisida+Alami). Diakses

pada 12 Februari 2015

Departemen Kesehatan. 1981. Kandungan

Zat Gizi Tanaman Bayam. http://www.depkes.ac.id. Diakses pada 20 Januari 2012.

Detik Forum. (2008). Pupuk Organik, Pupuk Hayati, Kandungan Nitrogen dan

Pupuk Kimia.

http://isroi.wordpress.com/2008/02/

26/pupuk-organik-pupuk-hayatidanpupuk-kimia. Diakses pada 7 Maret 2012.

Gembong. 2003. Morfologi

Tanaman Sayuran. 11- 91.

Yogyakarta: UGM Press.

Hadisoeganda, A. Widjaja.

W. 1996. Bayam Sayuran

Penyangga Petani di Indonesia.

http://www.bptpsultra@.deptan.go.id.

Diakses pada 20 Januari 2012.

Indriani dan Y. Hety. 2007. Membuat Kompos secara Kilat. Jakarta: Swadaya.
Marsono dan P. Sigit. 2002. Pupuk Akar Jenis dan Aplikasi. Jakarta: Penebar Swadaya.

Muhlisin, F. 1999. Temu-temuan dan EmponEmpon Budi Daya dan Manfaatnya. Yogyakarta: Kanisius.

Murbandono. 2006. Pupuk Organik alami,Pupuk Hayati, dan Pupuk Kimia. htpp://wordpress.com/2009/ 02/26/pupuk-organik-pupukhayatidan-pupuk-kimia/ Diakses pada 15 Mei 2011.

Musnawar. 2003. "Pupuk Alam yang berasal dari padat dan cair". Penelitian di Internet. World Wide. Web: http://js.unikom.ac.id. Diakses pada 13 September 2012.

Naswir. 2003. Pemanfaatan Urin Sapi yang Difermentasi sebagai Nutrisi Tanaman.

http://www.google.com/intl/en/help /features.html/cached. Diakses pada 15 Januari 2014.

Nurtjahya, Naswir, Ramadan. 2008. Produksi Urin Sapi potong, Harapan Petani

Nonpestisida.

http://www.kompas.com. Diakses pada 20 Desember 2012.

Parakasih, A. 2000. "Pengaruh Pengatur tumbuh Dosis Pupuk urine ternak sapi terhadap pertumbuhan dan produksi tanaman bayam." Jurnal Seri Ilmu Hayati. STPP Gowa. http://stppgowa.ac.id/download/Vol _3_No_1_2007/Tola.pdf. Diakses pada 8 Juni 2014.

Permentan No.2/Pert/Hk.060/2/2006.

Tentang Pengertian Pupuk Organik dan Pembenah Stuktur Tanah. http;/www,scribd,com/doc/1931585 
3/Pupuk Cair. Diakses pada 10 Maret 2012.

Pikiran Rakyat, 2006. Keunggulan

Makanan Fermentasi,

http://www.pikiran-rakyat.com/

cetak/0604/24/cakrawala/lainnya

02.htm. Diakses pada 9 Oktober 2012.

Pramonosidi. 2007. Pengolahan Limbah

Ternak. Sukoharjo: CV. Palem

AnNuur.

Pratikno. 2001. "Upaya Pencapaian

Sinkronisasi Nitrogen pada Budi

Daya Tanaman Selada. Fakultas

Pertanian Universitas Widyagama." $J$.

Tanah Trop., Vol. 14. No. 2, 200: 127-

134.

Raihan dan Nurtartiyani. 2001. Kandungan

Hara nitrogen.

www.nasih.staff.ugm.ac.id/pnt3404

kandang/. Diakses pada 9 April 2011.

Sugeng, Y. B. 2005. Beternak Sapi Potong.

Jakarta: Penebar Swadaya.

Sukamto. 2007. EM4 membantu

mempercepat proses pembuatan Syarief. P, dan Sumoprastowo, S. 1982.

pupuk. http://bioq- Ternak Perah. Cetakan Ke II. CV.

suka.blogspot.com/2007/07/

Yasaguna Jakarta.

I

4\%209417.docblora.org/forum/blog

phphttp://rioardi.wordpress.com/20

0 9/03/03/unsur-hara-dalam-

tanahmakro-dan-mikro/. Diakses

pada 29 Desember 2012.

Ramadhan. 2008. Urine Sapi, Harapan

Petani Nonpestisida.

http://www.kompas.com/kompascetak

/02.08/12/iptek/anth29.htm.
Diakses pada 29 Desember 2012.

Sarwono, B. dan Arianto, H. B. 2001.

Penggemukan Sapi Potong secara

Cepat. Jakarta: Penebar Swadaya.

Setiana. 2005. Teknik Penyuluhan dan

Pemberdayaan Masyarakat. Bogor:

Ghalia Indonesia.

Setjamidjaja dan Wirasmoko. 2000.

Nitrogen berperan

merangsang pertumbuhan vegetatif

sehingga tanaman tumbuh

tinggi.

http://sholihnugroho.blogspot.com/

2011/01/. Diakses pada 12 Maret

2012.

Sihombing, D. T. H. 2000. Teknik

Pengelolaan Limbah

Kegiatan/

Usaha Peternakan. Pusat Penelitian

Program Pascasarjana Universitas

Gadjah Mada Yogyakarta.

http://www.damandiri.or.id/detail.ph p?id=240, Diakses pada 8 Desember 2012. 
http://tohariyusuf.wordpress.com/

2009/04/25/kandungan-hara-

pupukfermentasi-urine-sapi-sebagai-

pupuk.html. Diakses pada 11

Desember 2012.

Sunarjono, H. 2008. Bertanam 30 Jenis

Sayuran. Jakarta: Penebar

Swadaya.

Suprapto, A. 2005. Petunjuk Pelaksanaan

Siaran Pedesaan dan Pedoman

Umum Metode

Penyuluhan

Pertanian. Jakarta: Badan

Pengembangan Sumber daya

Pertanian.

Suriadikarta. 2006. Permentan

No.2/Pert/Hk.060/2/2006 tentang Pupuk Organik dan Pembenahan

Tanah. Jakarta.

Suryabrata, S. 1992. Metodologi

Penelitian. Cetakan V. Jakarta:

Rajawali Press.

Susanto. R. 2004. Pupuk Cair Urine

Ternak Sapi, Harapan Petani

Nonpestisida.

http://www.kompas.com. Diakses

pada 20 Desember 2012.

Sutanto, R. 2006. Penerapan Pertanian

Organik. Penerapan

Pemasyarakatan dan

Pengembangannya. Yogyakarta:

Kanisius.

Syafrudin. 2003. "Pengaruh Media Cetak

Brosur dalam Proses Adopsi dan

Difusi Inovasi Beternak Ayam

Broiler di Kota Kendari." Tesis.

Program Studi Ekonomi Pertanian

Jurusan Ilmu-Ilmu

Pertanian Wibowo .2008.
Pemanfaatan Limbah Cair Ternak. http://sholihnugroho.blogspot.com/ 2 011/01/pemanfaatan-limbahcairternak-urin.html. Diakses 2 Maret 2012.

Wikipedia. 2008. Fermentasi. http://id.wikipedia.org/wiki/ferment asi. Diakses 23 Februari 2012. 